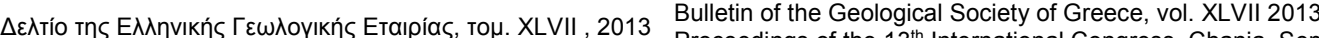
Proceedings of the $13^{\text {th }}$ International Congress, Chania, Sept.

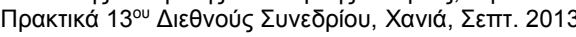
2013

\title{
AGGREGATE TRANSPORT AND UTILIZATION: ECOLOGICAL FOOTPRINT AND ENVIRONMENTAL IMPACTS
}

\author{
Agioutantis Z. ${ }^{1}$, Komnitsas K. ${ }^{1}$ and Athousaki A. ${ }^{2}$ \\ ${ }^{1}$ Department of Mineral Resources Engineering, Technical University of Crete, 73100 Hania, \\ Greecezach@mred.tuc.gr,komni@mred.tuc.gr \\ ${ }^{2}$ Civil Engineer, Hania
}

\begin{abstract}
The Ecological Footprint (EF) measures how much of the biosphere's annual regenerative capacity is required to renew the natural resources used by a defined population in a given year. In essence, the EF is a resource accounting tool that measures how much biologically productive land and sea is used by a given population or activity, and compares this with the available land and sea.

Productive land and sea support population demands for food, fiber, timber, energy, and space for infrastructure. These areas also absorb gaseous emissions (i.e. $\mathrm{CO}_{2}$ ) generated from human activities.

The present paper discusses a methodology that allows the parametric estimation of the EF due to the transport of aggregates to urban areas as a function of tonnage and distance.
\end{abstract}

Key words: quarry, emissions, sustainable aggregate management.

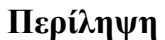

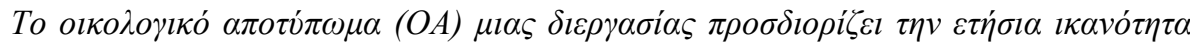

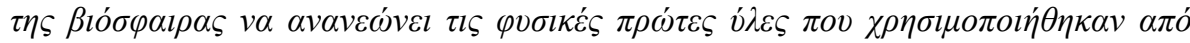

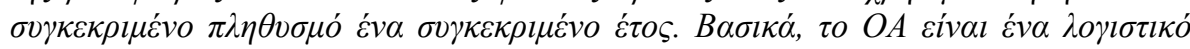

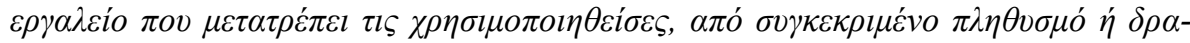

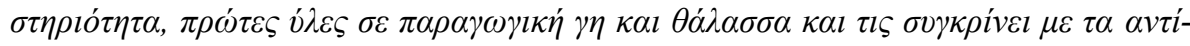

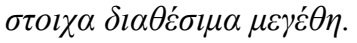

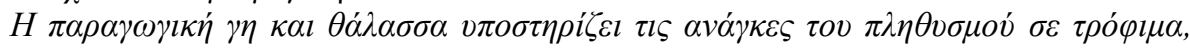

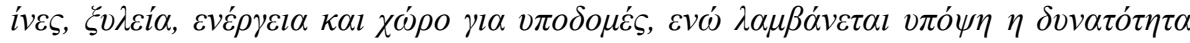

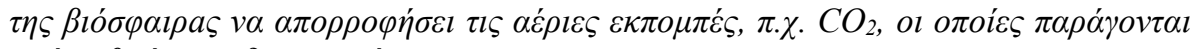
$\alpha \pi o ́ ~ \alpha \nu \theta \rho \omega ́ \pi \imath v \varepsilon \varsigma \delta \rho \alpha \sigma \tau \eta \rho t o ́ \tau \eta \tau \varepsilon \varsigma$.

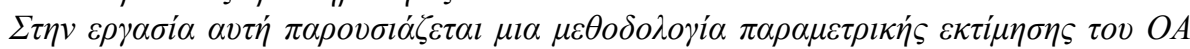

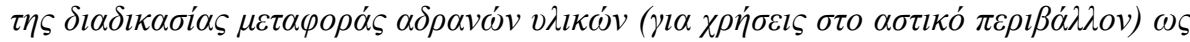

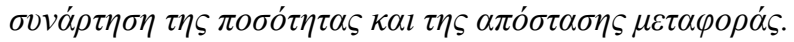

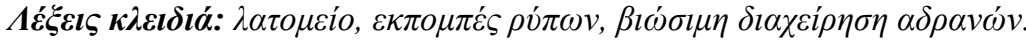




\section{Introduction}

Economic development is closely linked to the extraction and use of natural resources. Over the recent decades, however, the demand for natural resources has increased dramatically and has created huge environmental problems including biodiversity loss, ecosystem degradation and climate change, and, thus, it is now considered as a serious threat to the economic and social equilibrium of the planet. One of the key sustainability challenges for the following decades is to improve the management of natural resources in order to reduce current levels of anthropogenic environmental pressure.

The extensive use of natural aggregates in construction projects has been gradually depleting this resource near the areas where aggregates are in high demand. The need for resource conservation and longer transportation distances highlights the need to quantify the environmental impacts associated to aggregates production, transport and utilization as well as to assess potential and demand for substitute materials (Henry et al., 2011). Aggregates consist of natural, artificial or recycled materials. In essence, natural aggregates can be considered as non-renewable, nonmetallic and non-fossil mineral resources that are vital for modern societies. Natural aggregates are produced in surface or underground quarries, while artificial or recycled materials used for aggregates (i.e. broken glass, slag, etc) are processed in industrial plants.

The production of aggregates is the fastest growing activity worldwide since huge quantities (about 15 billion $\mathrm{t} / \mathrm{y}$ ) are required by the construction industry; the total direct value of this production is estimated to be in the order of $€ 20$ billion (UEPG, 2013). The U.S. Geological Survey (USGS) in its 2013 Mineral Commodity Summaries estimates that the U.S. aggregates production of 2.08 billion tons in 2012 increased by about 7.6 percent over 2011 numbers (USGS, 2013). The value of primary aggregates produced in the U.K was $£ 1.425 \mathrm{bn}$ in 2009 , representing nearly a 30 percent drop from values shown in 2006 through to 2008 of around $1.8 \mathrm{bn}$. The total aggregates sales in Great Britain in 2009 were 198 million tons. This is down from a peak in the late 1980s of 330 million tons of which 300 million were primary aggregates. Sales of recycled and secondary aggregates have grown steadily accounting for just over 50 million tones (UK Office of Fair Trading, 2011).

Construction aggregates are essential and valuable resources for the economic and social development. Recycled aggregates (RA) and natural aggregates (NA) are not therefore in competition, but their joint utilization is considered as strategic for the construction industry. Transportation contributes heavily to the life cycle impacts of aggregates. Under different assumptions relevant to transportation distances, and considering the type and grade of RA, as well as local availability of NA, it is possible to define the geographical coverage of market demand in order to identify and quantify energy consumption and environmental impacts (Blengini and Garbarino, 2010).

The quantity of aggregates used in construction applications varies from country to country and depends on the type, size and quality of applications. Table 1 presents estimates of aggregate consumption for two activities associated with urban areas: housing and road construction.

Table 1 - Estimates of aggregate consumption for two activities associated with housing and road construction.

\begin{tabular}{|l|l|l|l|}
\hline Country & Housing & Highways & Reference \\
\hline UK & 60 tons / average house & $\begin{array}{l}7,500 \mathrm{tons} / \mathrm{km} \mathrm{(single} \mathrm{mo-} \\
\text { torway lane) }\end{array}$ & Brown et al., 2008 \\
\hline US & 400 tons / average house & $\begin{array}{l}20,000 \text { tons } / \mathrm{km} \mathrm{(4} \mathrm{lane} \\
\text { highway) }\end{array}$ & USGS, 2006 \\
\hline Greece & $3.22 / \mathrm{m}^{2}$ of a house & 36,400 tons $/ \mathrm{km} \mathrm{(6} \mathrm{lane} \mathrm{road)}$ & $\begin{array}{l}\text { Kaliampakos and } \\
\text { Benardos, 2000 }\end{array}$ \\
\hline
\end{tabular}

$\underline{\text { XLVII, No } 3 \text { - } 1961}$ 
It is thus estimated that in the U.K 60 tons of aggregates are required for the construction of an average house (assuming that no construction of roads or other infrastructure is required); for the construction of $1 \mathrm{~km}$ of a single motorway lane 7,500 tons of aggregates are required. In the USA these figures amount to 400 and 5,000 tons respectively. In Greece, earlier studies estimate that 3.22 tons of aggregates are required for every $\mathrm{m}^{2}$ of a house, while for the construction of $1 \mathrm{~km}$ of a 6 lane highway 36,400 tons are required. Even if the number of large construction projects will decrease in the near future in this recession period, demand for aggregates is expected to continue at reasonable levels due to projected population growth and demand for infrastructure improvements and maintenance.

\section{Ecological Footprint}

\subsection{General Issues}

Sustainable development has become a primary objective for almost all countries since the late 1980s. A major difficulty associated with sustainable development objectives, however, is the absence of reliable indicators to measure progress towards the goal of sustainability. An accurate indicator to do so is the Ecological Footprint (EF) which measures how much of the biosphere's annual regenerative capacity is required to renew the natural resources used by a defined population in a given year. On an aggregate basis, the EF may be compared with the area of ecologically productive land available to provide an indication of whether consumption patterns are likely to be sustainable (Venetoulis and Talberth, 2006).

EFs can be calculated for individuals, groups of people (such as a nation), and activities (such as manufacturing a product). The EF is the leading biophysical accounting tool for comparing present aggregate human demand on the biosphere with the ecological capacity to sustain life (Niccolucci et al., 2012).

Recently, a number of organizations and governments have begun using the term Carbon Footprint (CF) to refer to the quantities of $\mathrm{CO}_{2}$ emissions associated with a specific activity, process, or product. This carbon footprint, typically measured in tons of $\mathrm{CO}_{2}$, is an initial step towards calculating a full $\mathrm{CF}$, which in turn is a percentage of the total EF. $\mathrm{CF}$ translates as tons of $\mathrm{CO}_{2}$ released and is measured as the total area, in global hectares, required to sequester these carbon emissions (GFN, 2008). A full CF systematically covers the complete supply chain and, therefore, all the stages of the lifecycle of a process or product in a systematic way. The footprint is strongly correlated with the per capita consumption expenditure. In Greece for example, the per capita GHG Footprint for 2001 was $13.7 \mathrm{tCO}_{2} e$ per person per year (py), while the construction sector accounted for 14\% (Hertwich and Peters, 2009).

Non-renewable fossil fuels are treated differently from other minerals since they actually represent ancient materials of biological origin, and their combustion releases $\mathrm{CO}_{2}$, which is part of the biosphere's material cycles. The footprint of carbon released from the combustion of fossil fuels is, therefore, defined as the productive area required to sequester the generated $\mathrm{CO}_{2}$ and prevent its accumulation. An alternative method would be to calculate the consumption of fossil fuels according to the productive area required to regenerate them, which would result in a CF much higher than the current calculation (GFN, 2008).

Non-renewable mineral resources, excluding fossil fuels, i.e., copper, iron, etc., do not have an EF in the same way as one ton of timber, which requires bio-productive area for its production. There is, however, an EF associated with the energy and other materials used in extracting, refining, processing, and shipping these mineral resources; all of these factors are often reported as the EF or CF of the specific mineral resource. At the same time, it should be emphasized that when mined materials such as mercury or arsenic enter the environment, they may cause damage and loss of productivity; all these impacts can be properly addressed in an appropriate Life Cycle Analysis (LCA) study, which is a method of accounting for the environmental impacts associated with a

$\underline{\text { XLVII, No } 3-1962}$ 
product, a process or a service (Chowdhury et al., 2010). Since aggregates are an abiotic resource, several other indicators can be used to assess environmental impacts in LCA studies. These can be based on a thermodynamic approach (use of energy or exergy indicators), on a mass flow approach (use of a total mass requirement indicator), on a surplus of energy that will be needed for future extractions (eco-indicator approach, Goedkoop and Spriensma, 2001) or on a scarcity approach.

Transportation includes emissions associated to the production of fuels, focusing on well-to-wheel analysis. Well-to-wheel is the specific LCA that is carried out for transport of fuels and vehicles, and is commonly used among others to assess total energy consumption, or the energy conversion efficiency and emissions impact of motor vehicles including their CF and the fuels used in this transport means. However, it does not take into account the production of the vehicles, which, alone, emitted some 1000 million metric tons of $\mathrm{CO}_{2}$ equivalent $\left(\mathrm{MtCO}_{2} e\right)$; this figure is comparable to aviation emissions. Life-cycle assessments indicate that about half of the GHG emissions of the car manufacturing sector are related to materials, and since car manufacturing involves complex international supply chains, a detailed analysis of the emissions from the production of imported products is essential (Hertwich and Peters, 2009).

\subsection{Definitions}

The EF is usually measured in 'global hectares'. A global hectare is defined as a hectare with world-average productivity for all biologically productive land and water in a given year. Biologically productive land includes areas such as cropland, forest, and fishing grounds, and excludes deserts, glaciers, and the open ocean (GFN, 2008).

Some researchers and organizations measure the EF in productive hectares, land hectares or forest hectares, while others in tons of carbon instead of carbon dioxide or in hectares/year. Table 2 presents a comparison of a number of definitions. It is immediately evident that there is a wide range of values for the EF. The evaluation of the assumptions and results for each study is beyond the scope of the present paper.

It is known that oceans cover $72 \%$ of the earth's surface, while forests cover around $29 \%$ of continents. Based on this data, extreme values shown in Table 2 and representing only specific systems were disregarded and values involving global hectares were considered; the more representative value of 3.75 tons $\mathrm{CO}_{2} /$ year/hectare was used in this study.

Construction aggregates are usually transported in bulk in large trucks or containers in order to achieve economy of scale. A typical unit used for freight calculations is expressed as the product of [Payload x Distance]; this is commonly expressed as a ton-km. The transportation cost decreases as the cost per ton-km decreases. Figure 1 presents a conceptual diagram of how supply locations A and B may service demand locations 1, 2, and 3. The products A1, A2, A3 and B1, B2, $\mathrm{B} 3$ correspond to the resulting ton-km for each route. The issue becomes more complicated when two or more sources of aggregates are available in a given area. Large trucks will achieve a lower unit transportation cost, but appropriate road infrastructure should be available.

\section{Estimating the EF of Aggregate Transport}

In this study, emphasis was given to the utilization of conventional transport vehicles and principally the consumption of fuel, which is the dominating component of this operation. The production chain of fuel including crude oil extraction, refining and distribution as well as the manufacturing of production plants and the manufacturing of vehicles was not taken into account. The average fuel consumption per ton-km is based on the work by Erkkila (2005) (Figure 2). 


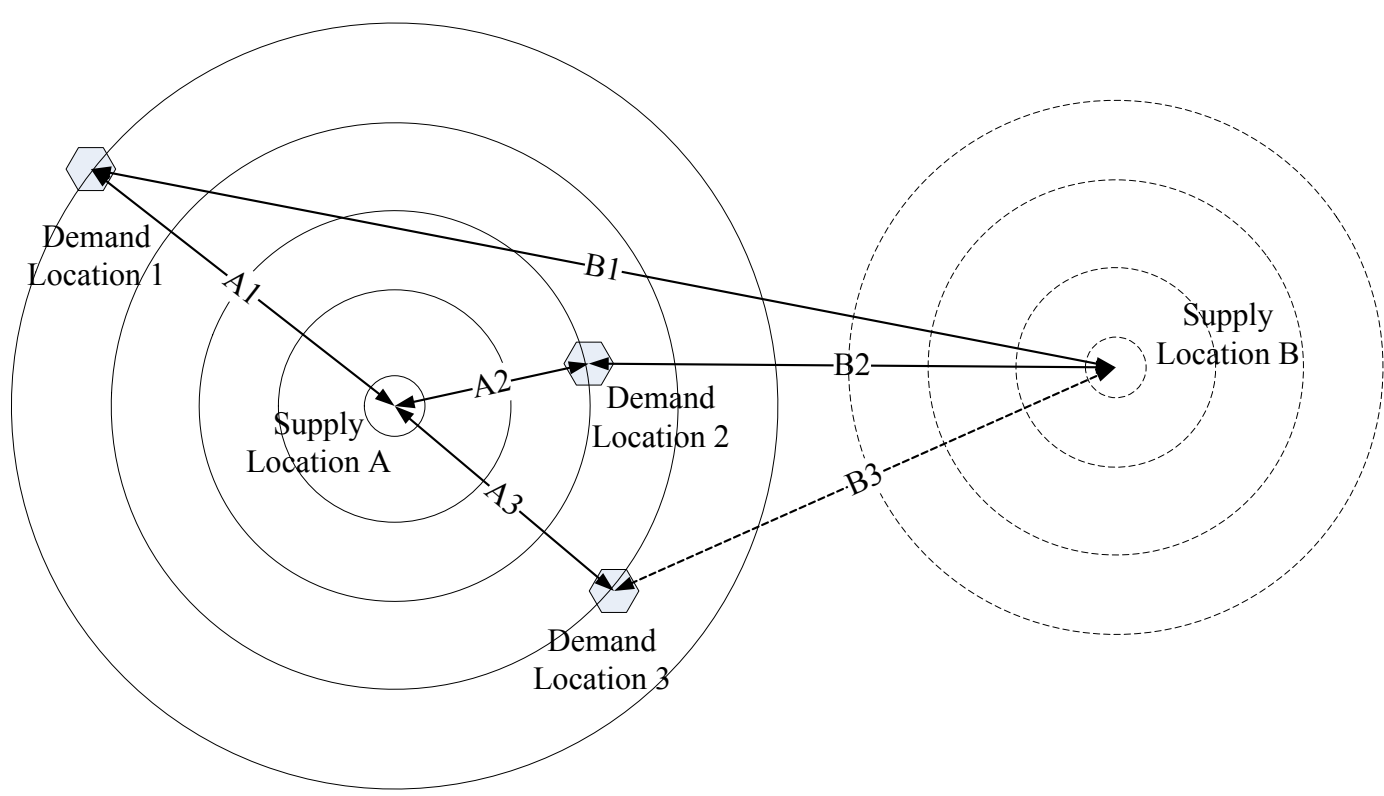

Figure 1 - Conceptual diagram of transportation options between two supply and three demand locations.

Table 2 - Definitions of Ecological Footprint.

\begin{tabular}{|l|c|l|}
\hline Hectare description & $\begin{array}{c}\text { EF } \\
\mathbf{C O} \mathbf{y}^{-1} \mathbf{h a}^{-1}\end{array}$ & Reference \\
\hline $\begin{array}{l}\text { Productive hectare (unproductive land and water surface } \\
\text { areas were excluded) }\end{array}$ & 0.059 & Zhang (2005) \\
\hline $\begin{array}{l}\text { Global hectare (EFs have been calculated for six land } \\
\text { use categories) }\end{array}$ & 3.73 & $\begin{array}{l}\text { EPA Victoria (2005); } \\
\text { Wackernagel et at. } \\
\text { (2004) }\end{array}$ \\
\hline $\begin{array}{l}\text { Global hectare (includes the entire surface of the Earth } \\
\text { in biocapacity) }\end{array}$ & 0.22 & $\begin{array}{l}\text { Venetoulis and Tal- } \\
\text { berth (2006) }\end{array}$ \\
\hline $\begin{array}{l}\text { Forest hectare (Natural eucalypt forest systems of NSW } \\
\text { Australia) }\end{array}$ & 0.15 & Livesley (2007) \\
\hline Forest hectare (environmental trees at age 10) & $5-10$ & Carruthers (2008) \\
\hline Forest hectare in high rainfall regions & 20 & Carruthers (2008) \\
\hline Forest of growing trees & 6 & UNEP (2008) \\
\hline Global hectare of year 2003, fossil fuel & 3.77 & WWF (2006) \\
\hline
\end{tabular}




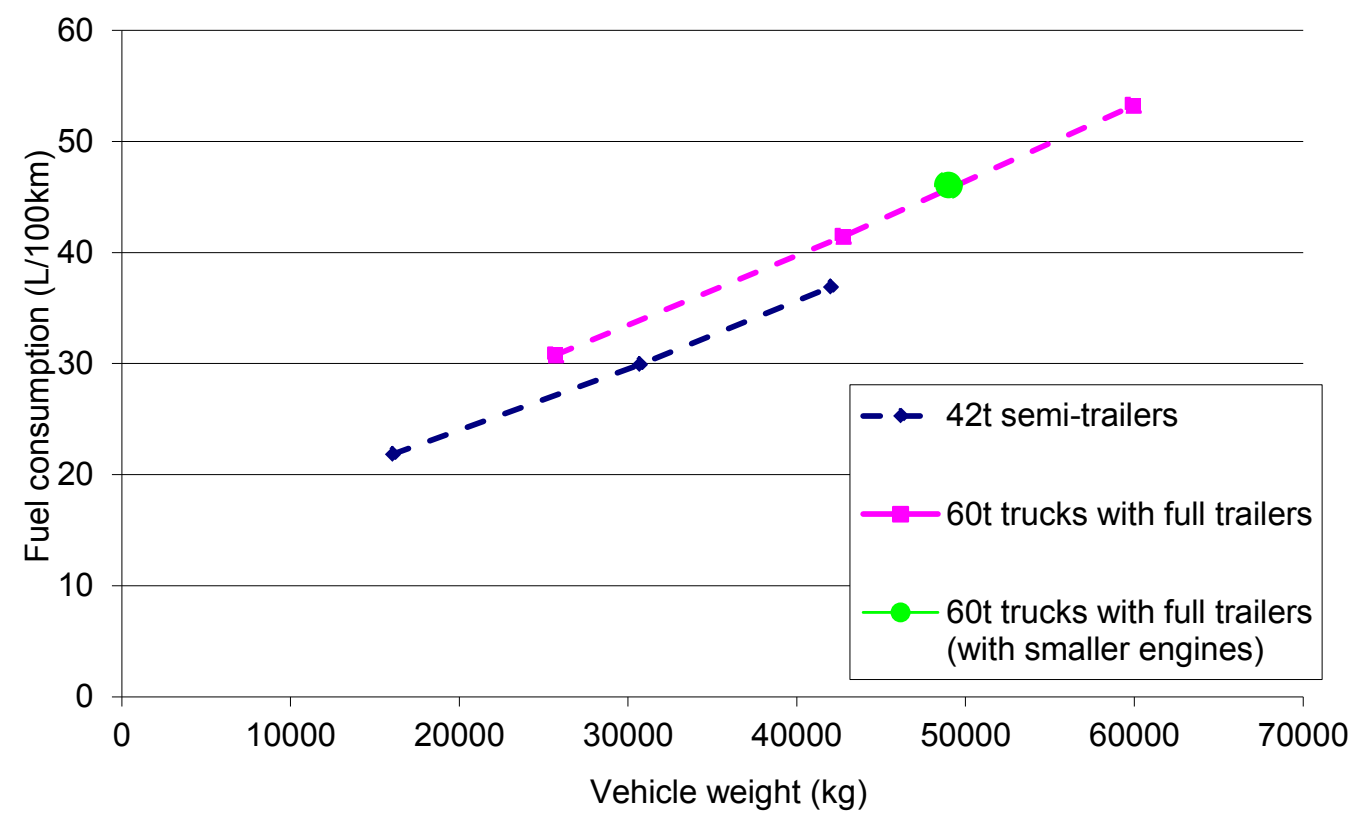

Figure 2 - Estimation of fuel consumption on highway cycle (Erkkila, 2005).

In order to estimate the EF of aggregate transport the following assumptions/simplifications are considered:

- Only large trucks are used.

- Highway cycle is applied.

- Fuel consumption is converted to fuel emissions assuming the use of diesel fuel.

- Only $\mathrm{CO}_{2}$ emissions are taken into account (i.e. equivalent $\mathrm{NO}_{\mathrm{x}}$ or $\mathrm{SO}_{\mathrm{x}}$ emissions are ignored).

- Using data for 60ton trucks (which corresponds to a payload of about 35 tons), it is calculated that the consumption on a highway cycle is about $55 \mathrm{~L} / 100 \mathrm{~km}$. This value is quite similar to the value suggested by EPA for truck mileage which is in the order of $5 \mathrm{mpg}$ (miles per US gallon; US 2007), or about $47 \mathrm{~L} / 100 \mathrm{~km}$. Hence the consumption per ton-km was taken as $0.0148 \mathrm{~L} /$ ton-km. Similar data compiled for the British Department of Transport can be summarized in Table 3 (UK Department of Transport, 2007).

Figure 3 presents the steps utilized in order to perform the parametric analysis. For each step the following data/assumptions were used:

- Based on Table 3, a higher fuel consumption, in terms of L/ton-km, was considered for smaller trucks under the assumption that for every 5 tonne reduction of payload, the specific fuel consumption increases by $0.001 \mathrm{~L} /$ ton-km.

- The $\mathrm{CO}_{2}$ emitted per liter of diesel was taken as $2.6 \mathrm{~kg} \mathrm{CO}$ per liter (UNEP, 2008). Thus $\mathrm{CO}_{2} e$ was calculated.

- To convert the $\mathrm{CO}_{2} e$ to the area required to absorb the emitted $\mathrm{CO}_{2}$ the value of 3.7 tons $\mathrm{CO}_{2} /$ year/hectare was used. It should be noted that similar graphs can be generated for any value of tons $\mathrm{CO}_{2} /$ year/hectare. 


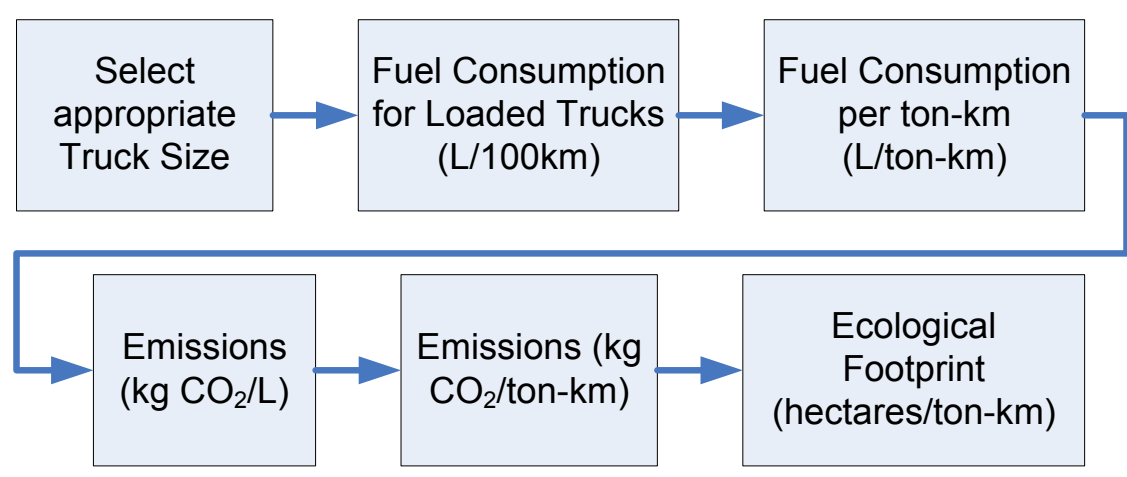

Figure 3 - Steps in parametric analysis.

Table 3 - Specific fuel consumption for truck transport (UK Dept. of Transport, 2007).

\begin{tabular}{|l|c|c|}
\hline Condition & Miles per gallon & Liters per ton-km \\
\hline 44 tonne truck empty (16 tonnes) & 10.27 & 0.017 \\
\hline 10 tonnes cargo & 7.44 & 0.015 \\
\hline 16 tonnes cargo & 6.53 & 0.014 \\
\hline 28 tonnes cargo & 5.51 & 0.012 \\
\hline
\end{tabular}

The results derived are presented in the form of parametric graphs. Figure 4 shows a chart for consumption $(\mathrm{L} / 100 \mathrm{~km})$ versus distance $(\mathrm{km})$ for different truck payloads. It is evident that the absolute consumption increases with the heavier trucks, while the specific consumption ranges from $0.012 \mathrm{~L} /$ ton- $\mathrm{km}$ for the 35 tonne payload to $0.017 \mathrm{~L} /$ ton $-\mathrm{km}$ for the 10 tonne payload.

Figure 5 shows the $\mathrm{CO}_{2}$ e for a 10 tonne payload trucked under different conditions. In this case, the $\mathrm{CO}_{2}$ decreases when the specific fuel consumption decreases for higher payloads. As an example, 10 tonnes of aggregates trucked for a distance of $50 \mathrm{~km}$ using a 10 tonne payload truck will generate about $22 \mathrm{~kg}$ of $\mathrm{CO}_{2} e$, while if the same material is trucked in a 35 tonne payload truck it will generate about $15 \mathrm{~kg}$ of $\mathrm{CO}_{2} e$.

\section{Other Issues for Consideration}

\subsection{Transport Cost}

Aggregate transport cost cannot be easily compared between countries. It is known that diesel prices differ substantially among USA, EU Member States, South East Europe (SEE countries) and Eastern Europe, Caucasus and Central Asia (EECCA countries) (EEA, 2012), making thus difficult to compare costs for the transport of aggregates in different regions. Usually fuel prices increase by 3 cents per litre for each USD increase in the oil price per barrel, but this is not the case in several countries. By taking into account different custom costs and increased taxation, imposed on fuels in this recession period in many parts of the world, it is difficult to predict diesel prices in the future and thus calculate and compare cost of transport. A very good example is the evolution of diesel price in Luxembourg and Italy as a result of the increase of oil price in 2007. When the start of the year one barrel oil cost 50.77 USD, 1 L diesel was sold for $0.85 €$ in Luxembourg and for $1.16 €$ in Italy. The barrel price increased about $72.58 \%$ until the end of year 2007 and was sold 87.62 USD in December. For the same period the increase in the price of one litter of diesel was $14.11 \%$ in Luxembourg and $17.24 \%$ in Italy.

XLVII, No $3-1966$ 


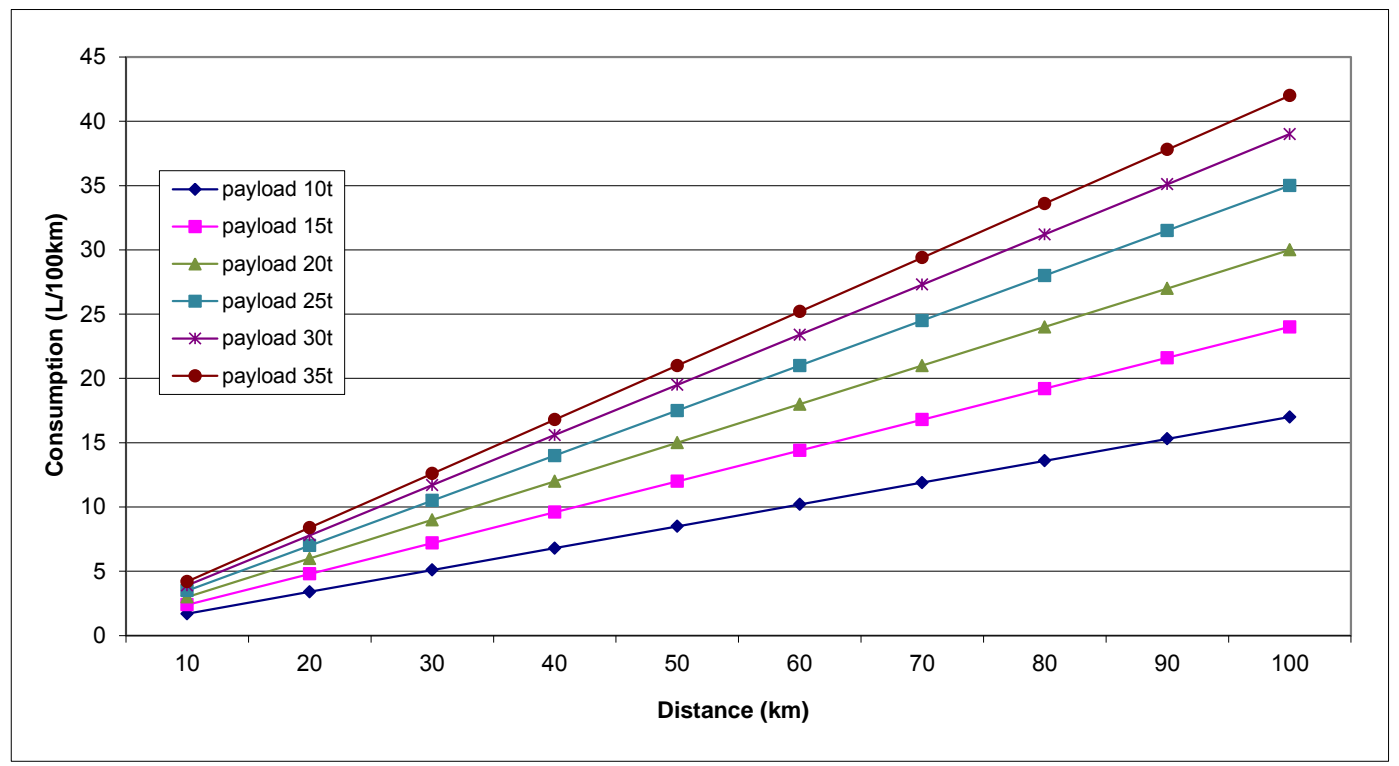

Figure 4 - Consumption vs Distance.

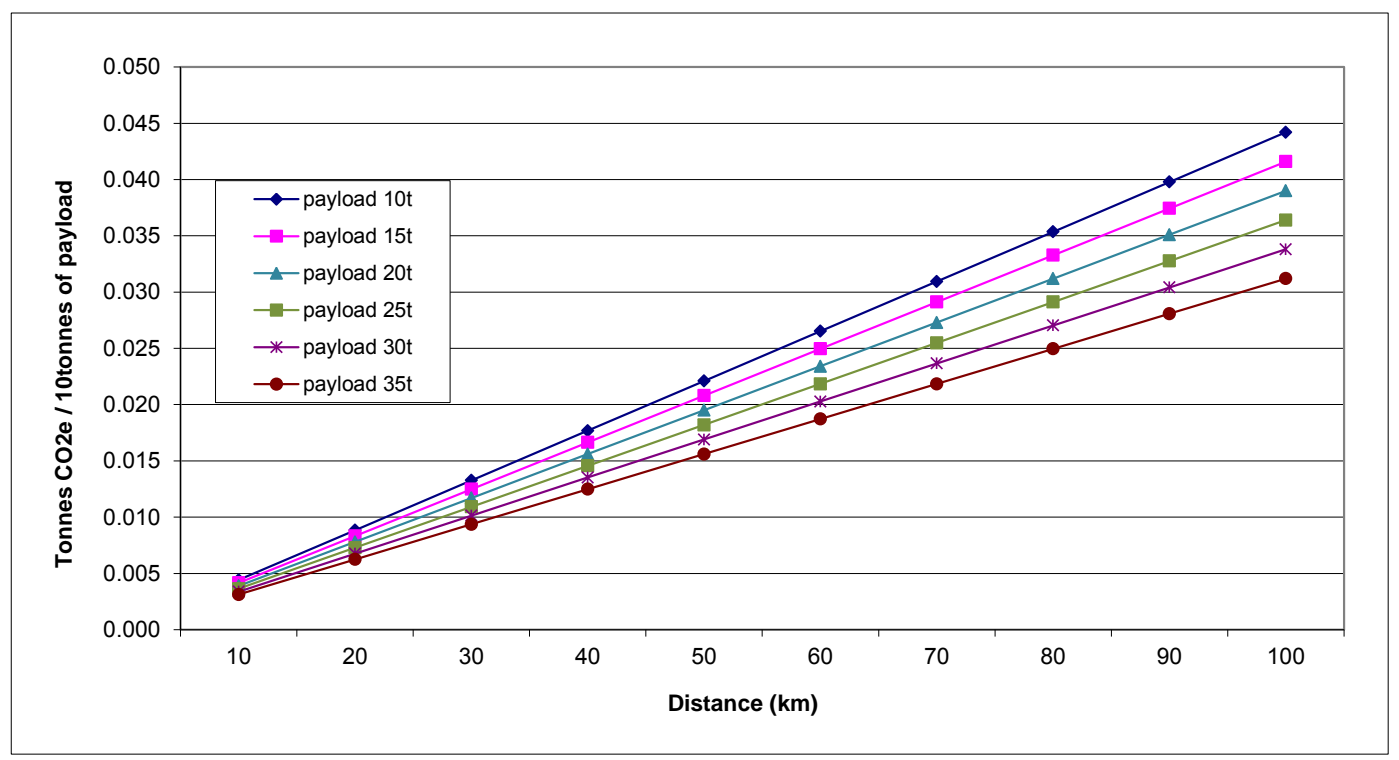

Figure 5 - Equivalent tonnes of $\mathrm{CO}_{2}$ as a function of specific payload.

\subsection{Intermediate Transport Stations}

As quarries are pushed away from the urban and suburban environment, transfer of aggregates to the urban consumers becomes more expensive and more challenging. In addition, the EF of such operations is definitely becoming higher, especially if smaller vehicles are used to transport aggregates for longer distances.

A sustainable solution proposed in this paper is to use transport stations close to urban environments. Thus, bulk material can be transported in large vehicles, trains or boats if possible to intermediate stations, and then distributed to the consumer using smaller vehicles. The EF of 
such an operation should be calculated by taking into account the EF for unloading, reloading and maintaining aggregate stockpiles in transport stations. The wide utilization of ready mix stations, except for the quality advantage, contributes to the reduction of the EF footprint of aggregate transport, since only the necessary materials will be transported to the end user and in the requested quantity.

\section{Conclusions}

The need for resource conservation and longer transportation distances highlights the importance to quantify the environmental impacts associated to aggregates production, transport and utilization as well as to assess potential and demand for substitute materials. In this paper a methodology followed for a parametric estimation of the Environmental Footprint (EF) for the transport of aggregates for urban applications as a function of tonnage and distance is presented.

Fuel consumption, in terms of L/ton-km, was calculated for different truck payloads. It was assumed that for every 5 tonne reduction of payload, the specific fuel consumption increases by $0.001 \mathrm{~L} /$ ton-km. The $\mathrm{CO}_{2} e$ was calculated using the estimated $\mathrm{CO}_{2}$ emissions per liter of diesel. In order to convert the $\mathrm{CO}_{2} \mathrm{e}$ to the area required to absorb the emitted $\mathrm{CO}_{2}$ the value of 3.7 tons $\mathrm{CO}_{2} /$ year/hectare was used. It was calculated that 10 tonnes of aggregates trucked for a distance of $50 \mathrm{~km}$ using a 10tonne payload truck will generate about $22 \mathrm{~kg}$ of $\mathrm{CO}_{2} e$, while when the same material is trucked in a 35tonne payload truck it will generate about $15 \mathrm{~kg}$ of $\mathrm{CO}_{2} \mathrm{e}$.

Finally, by considering the probability that in the near future a number of quarries will be relocated and new quarries will be sited far away from urban centres, the establishment of intermediate transport stations close to urban environments seems to be a feasible and sustainable option.

\section{Acknowledgements}

The authors would like to acknowledge the financial support of the European Commission for the projects SARMa (Sustainable Aggregates Resource Management), Contract No SEE AF/A/151/2.4/X (www.sarmaproject.eu), and SNAP-SEE (Sustainable Aggregates Planning in South East Europe), Contract No SEE/D/0167/2.4/X (http://www.snapsee.eu).

\section{References}

Blengini G.A. and Garbarino E. 2010. Resources and waste management in Turin (Italy): the role of recycled aggregates in the sustainable supply mix, J. Clean Prod., 18, 1021-1030.

Brown T.J., McEnvoy F., Mankelow J., Ward J., Bloomfield S., Goussarova T., Shah N. and Souron L. 2008. The need for indigenous aggregates production in England, British Geological Survay Open Report, OR/08/026, 74 pp.

Carruthers I. 2008. International, Land and Analysis Division, Australian Greenhouse Office, URL:http://www.abc.net.au/science/expert/realexpert/energy/05.htm (accessed January 18, 2013)

Chowdhury R., Apul D. and Fry T. 2010. A life cycle based environmental impacts assessment of construction materials used in road construction, Resour. Conserv. Recycl., 54, 250-255.

EEA (European Environment Agency), http://www.eea.europa.eu/data-and-maps/figures/petroland-diesel-fuel-prices-in-europe-by-region (accessed January 25, 2013)

EPA Victoria 2005. EPA Ecological Footprint Calculators: Technical Background Paper, http://epanote2.epa.vic.gov.au/EPA/Publications.nsf/2f1c2625731746aa4a256ce90001cbb5 /f4750e35750290ecca256fbd000b030c/\$FILE/972.pdf (accessed January 11, 2013)

Erkkila K. 2005. Heavy-duty truck emissions and fuel consumption simulating real-world driving in laboratory conditions, 2005 DEER Conference, 21-25 August, Chicago, Illinois, USA.

GFN (Global Footprint Network) 2008. http://www.footprintnetwork.org/, (accessed January 18, 2013).

$\underline{\text { XLVII, No } 3-1968}$ 
Goedkoop M. and Spriensma R. 2001. The Eco-indicator 99, a damage oriented method for Life Cycle Impact Assessment, methodology report. PRé Consultants B.V., 132 pp. http://www.pre.nl (accessed March 1, 2013)

Henry M., Pardo G., Nishimura T. and Kato Y. 2011. Balancing durability and environmental impact in concrete combining low-grade recycled aggregates and mineral admixtures, Resour. Conserv. Recycl., 55, 1060-1069.

Hertwich E. and Peters A. 2009. Carbon Footprint of Nations: A Global, Trade-Linked Analysis, Environ. Sci. Technol., 43, 6414-6420.

Kaliampakos D. and Benardos A. 2000. Quarrying and sustainable development in large urban centres: A contradiction in terms?, CIM Bull., 93, 86-89.

Livesley S. 2007. Mitigating greenhouse gases, http://www.onlineopinion.com.au/view.asp?article=6257 (accessed March 11, 2013)

Niccolucci V., Tiezzi E., Pulselli F.M. and Capineri C. 2012. Biocapacity vs Ecological Footprint of world regions: A geopolitical interpretation, Ecol. Indic., 16, 23-30.

UEPG (European Aggregates Association) 2013. http://www.uepg.eu/statistics/current-trends (accessed Feb. 28, 2013)

UNEP 2008. Tool 18 (excel inventory option), sheet 'Impacts-Climate Change', United Nations Environment Programme, www.unep.org/tut-unep/tolkit/index.htm (accessed 19 March 2013

UK Department of Transport 2007. Effects of payload on the fuel consumption of trucks, http://www.freightbestpractice.org.uk/effects-of-payload-on-fuel-consumption-of-trucks/ (accessed March 15, 2013).

UK Office of Fair Trading 2011. Aggregates. Report on the market study and proposed decision to make a market investigation reference, August 2011, Fleetbank House, 2-6 Salisbury Square, London EC4Y 8JX

US 2007. Combination Truck Fuel Consumption and Travel, table 4-14, http://www.bts.gov/publications/ national transportation statistics/2007/index.html

USGS (U.S. Geological Survey) 2006. Materials in use in U.S. interstate highways, Fact Sheet 2006-3127, October 2006, http://pubs.usgs.gov/fs/2006/3127/2006-3127.pdf (accessed March 5, 2013).

USGS (U.S. Geological Survey) 2013. Mineral commodity summaries 2013: U.S. Geological Survey, 198 p., Reston, Virginia, January 24, 2013

Venetoulis J. and Talberth J. 2006. Refining the ecological footprint, Environ. Dev. Sustain., 10, 441-469.

Zhang T. 2005. Ecological footprint budgeting: Environmental analysis of the generic American car. Green Manufacturing Group, Laboratory for Manufacturing and Sustainability, UC Berkeley, http://www.escholarship.org/uc/item/55z9v0f2, (accessed March 7, 2013)

Wackernagel M., White K.S. and Moran D. 2004. Using Ecological Footprint accounts: from analysis to applications, Int. J. Environ. Sust. Dev., 3, 293-315.

WWF 2006. Living Planet Report 2006,

http://wwf.panda.org/about_our_earth/all_publications/living_planet_report/living_planet_r eport timeline/lp_2006/, (accessed January 9, 2013) 